\title{
Dietary bioaccumulation potential of
} silver nanomaterials compared to silver nitrate in wistar rats using an ex vivo gut sac technique

Clark, Nathaniel

http://hdl.handle.net/10026.1/15718

10.1016/j.ecoenv.2020.110745

Ecotoxicology and Environmental Safety

Elsevier BV

All content in PEARL is protected by copyright law. Author manuscripts are made available in accordance with publisher policies. Please cite only the published version using the details provided on the item record or document. In the absence of an open licence (e.g. Creative Commons), permissions for further reuse of content should be sought from the publisher or author. 


\title{
Dietary bioaccumulation potential of silver nanomaterials compared to silver nitrate in wistar rats using an ex vivo gut sac technique
}

\author{
Nathaniel J. Clark ${ }^{\mathrm{a}}$, Waldemar Woznica ${ }^{\mathrm{b}}$, Richard D. Handy ${ }^{\mathrm{a}, *}$ \\ ${ }^{a}$ School of Biological and Marine Sciences, University of Plymouth, Plymouth, United Kingdom \\ ${ }^{\mathrm{b}}$ Biological Services Unit, University of Plymouth, Plymouth, United Kingdom
}

\section{A R T I C L E I N F O}

\section{Keywords:}

Gut exposure

Silver sulphide nanoparticles

Bioavailability

Alternative methods

3Rs

Rapid testing

\begin{abstract}
A B S T R A C T
Chronic dietary bioaccumulation tests with rodents are required for new substances, including engineered nanomaterials (ENMs), in order to provide information on the potential hazards to human health. However, screening tools are needed to manage the diversity of ENMs and alternative methods are desirable with respect to animal welfare. Here, an ex vivo gut sac method was used to estimate the dietary bioaccumulation potential of silver nanomaterials. The entire gastrointestinal tract (except the caecum) was removed and filled with a gut saline containing $1 \mathrm{mg} \mathrm{L}^{-1}$ of $\mathrm{Ag}$ as either $\mathrm{AgNO}_{3}$, silver nanoparticles (Ag NPs) or silver sulphide nanoparticles $\left(\mathrm{Ag}_{2} \mathrm{~S}\right.$ NPs), and compared to controls with no added $\mathrm{Ag}$. The gut sacs were incubated for $4 \mathrm{~h}$, rinsed to remove excess media, and the total Ag determined in the mucosa and muscularis. There was no detected Ag in the control treatments. Within the Ag treatments, $1.4-22 \%$ of the exposure dose was associated with the tissues and serosal saline. Within the mucosa of the $\mathrm{AgNO}_{3}$ treatment, the highest $\mathrm{Ag}$ concentration was associated with the intestinal regions (3639-7087 $\mathrm{ng} \mathrm{g}^{-1}$ ) compared to the stomach $\left(639 \pm 128 \mathrm{ng} \mathrm{g}^{-1}\right)$. This pattern was also observed in the $\mathrm{Ag} \mathrm{NP}$ and $\mathrm{Ag}_{2} \mathrm{~S}$ NP treatments, but there was no significant differences between any $\mathrm{Ag}$ treatments for the mucosa. However, differences between treatments were observed in the muscularis concentration. For example, both the $\mathrm{Ag} \mathrm{NP}\left(907 \pm 284 \mathrm{ng} \mathrm{g}^{-1}\right)$ and $\mathrm{Ag}_{2} \mathrm{~S} \mathrm{NP}\left(1482 \pm 668 \mathrm{ng} \mathrm{g}^{-1}\right)$ treatments were significantly lower compared to the $\mathrm{AgNO}_{3}$ treatment $\left(2514 \pm 267 \mathrm{ng} \mathrm{g}^{-1}\right)$. The duodenum demonstrated serosal accumulation in both the $\mathrm{AgNO}_{3}\left(\sim 10 \mathrm{ng} \mathrm{mL}^{-1}\right)$ and $\mathrm{Ag} \mathrm{NP}\left(\sim 3 \mathrm{ng} \mathrm{mL}{ }^{-1}\right)$ treatments. The duodenum showed some of the highest $\mathrm{Ag}$ accumulation with 41,61 and $57 \%$ of the total $\mathrm{Ag}$ in the mucosa compared to the muscularis for the $\mathrm{AgNO}_{3}, \mathrm{Ag} \mathrm{NP}$ and $\mathrm{Ag}_{2} \mathrm{~S} \mathrm{NP}$ treatments, respectively. In conclusion, the ex vivo gut sac method demonstrates the uptake of $\mathrm{Ag}$ in all $\mathrm{Ag}$ treatments, with the duodenum the site of highest accumulation. Based on the serosal saline accumulation, the ranked order of accumulation is $\mathrm{AgNO}_{3}>\mathrm{Ag} \mathrm{NPs}>\mathrm{Ag}_{2} \mathrm{~S} \mathrm{NPs}$.
\end{abstract}

\section{Introduction}

Engineered nanomaterials (ENMs) are being incorporated into food and food-based products (reviews, Bouwmeester et al., 2014; Chaudhry et al., 2008; Tiede, 2008), and inevitably there is the potential for human exposure of the gastrointestinal tract (GIT); yet the subsequent accumulation of ENMs across the mammalian GIT remains unclear. There are also concerns that ENMs can be incidentally incorporated into the human food chain from agriculture (e.g., nano pesticides) as well as from food processing, including anti-caking agents (Martirosyan and Schneider, 2014). Indeed, ENMs are also intended for direct consumption in health foods and nutritional supplements (Katouzian and Jafari, 2016), as well as in oral medicines for improved drug delivery or as inert fillers in the manufacture of pills (Bobo et al., 2016). Data on the measured concentrations of ENMs in food are now beginning to emerge (e.g., confectionary, Peters et al., 2014b; chicken meat, Peters et al., 2014a). The inclusion of metal-containing ENMs can be a few $\mu \mathrm{g}$ $\mathrm{kg}^{-1}$ of food (e.g., $\mathrm{TiO}_{2}$, Weir et al., 2012), to $\mathrm{mg} \mathrm{L}^{-1}$ concentration in sports drinks (e.g., silver, Reed et al., 2014).

For the nutritionally required metals such as $\mathrm{Cu}$, the solute transport pathways are well described, and the export of metal from the gut epithelial cell to the blood is concentration-dependent and the rate limiting step in absorption (Handy et al., 2000; Linder, 2002). Nonessential metals, such as $\mathrm{Hg}$ may also use some of these pathways (Hoyle and Handy, 2005), but the situation for dissolved Ag is less clear in mammals. Alternatively, ENMs may be taken up in the particulate form. The apical uptake (i.e., from the gut lumen side into the cells) of intact particles has been demonstrated in cultures of intestinal

\footnotetext{
* Corresponding author.

E-mail address: r.handy@plymouth.ac.uk (R.D. Handy).
} 
epithelial cells (Caco-2) and the uptake may also be dependent on the crystal structure of the material (e.g., $\mathrm{TiO}_{2}$, Gitrowski et al., 2014), and/ or particle size (e.g., silver, van der Zande et al., 2016). For the mammalian gut, in vivo, the $\mathrm{M}$ cells of the Peyer's patches are especially associated with the uptake of iron particles (Powell et al., 2010) and one concern is that these specialised structures could be a route for the preferential accumulation of particulates across the gastrointestinal tract. For $\mathrm{TiO}_{2}$ in rodents at least, only a small fraction of the ingested dose is taken up as particles in vivo (Kreyling et al., 2017). For Ag NPs, oral gavage studies lasting 86 days show approximately $5-37 \mathrm{ng} \mathrm{g}^{-1}$ of total $\mathrm{Ag}$ in the internal organs and with the most in the liver (van der Zande et al., 2012). A similar oral gavage study with Ag NPs in rodents over 28 days found approximately $0.1-2.6 \mu \mathrm{g} \mathrm{g}^{-1}$ wet weight of total $\mathrm{Ag}$ in the internal organs, with most in the liver and kidney (Loeschner et al., 2011). The latter reported negligible Ag excretion in the urine. Both studies reported more total $\mathrm{Ag}$ in the internal organs from exposure to dissolved silver salts than from exposure to the nanomaterials.

Although there have been oral gavage studies with rodents showing that ENMs can be taken up (form unknown) via the gut into the internal organs, the precise mechanisms of uptake for Ag NPs is unclear. Silver NPs may show some dissolution under the simulated acid conditions found in the stomach (Clark et al., 2019a), but any Ag could form a sparingly soluble $\mathrm{AgCl}$ particulate in the intestine (see discussion in Clark et al., 2019b). Such particles formed from the dissolved metal have also been detected in the internal organs (in trout, Clark et al., 2019c). Pristine Ag NPs may also be transformed into sparingly soluble $\mathrm{Ag}_{2} \mathrm{~S}$ NPs by sulfidation reactions (Lead et al., 2018). In the gut lumen, Ag NPs will inevitably be in close association with the food matrix which is enriched with sulphur residues (see Peters et al., 2014a), and in the reducing environment of the lumen (Wien and Van Campen, 1991), silver sulphide nanoparticles will form. Consequently, the sulfidised form of $\mathrm{Ag}$ should also be included in the hazard assessment.

In Europe, oral toxicity tests with rodents are a mandatory part of hazard assessment of new substances, including ENMs, and especially when oral exposure to humans is a route of concern (e.g., TG 407 OECD, 2008). However, with a myriad of forms and chemistries of ENMs, there are too many variants of the materials to test each one as a new substance, and so screening methods are needed to identify ENMs that present a bioaccumulation concern, as well as to reduce the burden of animal testing (Handy et al., 2018). In vitro studies with gut cell cultures show that $\mathrm{Ag}$ accumulation from $\mathrm{AgNO}_{3}$ has shown a chloride dependence, but not for Ag accumulation from citrate-coated Ag NPs (RTgutGC cells, Minghetti and Schirmer, 2016). However, this chloride dependent effect on $\mathrm{Ag}$ accumulation in gut epithelial cells is not observed in whole gut tissue, and is likely masked by the effects of mucus and the electrophysiological properties of the intact gut (Clark et al., 2019b); demonstrating the importance of this physiology. Nonetheless, reducing the need for in vivo testing is desirable and the ex vivo gut sac retains the physiological integrity observed in vivo.

The use of gut sacs from rodents has been long established for investigating gastrointestinal physiology (Wilson and Wiseman, 1954), the uptake of metals (Cu, Wapnir and Stiel, 1987; Cd, Hoadley and Johnson, 1987), but not so far applied to ENMs. The present study aimed to determine the bioavailability of Ag materials to the different anatomical regions of the rodent gastrointestinal tract when presented as either $\mathrm{AgNO}_{3}, \mathrm{Ag} \mathrm{NPs}$ or $\mathrm{Ag}_{2} \mathrm{~S}$ NPs. The serosal solution was also explored for evidence of any transepithelial uptake of Ag materials. The experimental approach used the same methodology as our previous report on the gut sacs of rainbow trout exposed to silver (Clark et al., $2019 b)$ to enable a direct cross-species comparison between fish and rodents for exactly the same batches of nanomaterial.

\section{Methodology}

\subsection{Stock animals}

Wistar rats (Rattus norvegicus) were bred in house at Plymouth University and kept until 7 weeks old. Rats $(n=24)$, weighing $100-150 \mathrm{~g}$, were housed in cages maintained at $20 \pm 2{ }^{\circ} \mathrm{C}$, humidity $55 \pm 10 \%$, and with a 12-h light/dark cycle and light intensity between 320 and 290 lux. Animals had free access to drinking water and food. Rats were fed a commercially available diet (RM3A [P], $9.5 \mathrm{~mm}$ pellets, Special Diet Services, England), containing crude fat, protein, fibre and ash of 4.2, 22.4, 4.2 and $7.6 \%$, respectively. Prior to the experiments, food was withheld for $24 \mathrm{~h}$ to aid in the evacuation of the gastrointestinal tract and faecal material was continuously removed to prevent coprophagic behaviour. Despite these efforts to clear the gastrointestinal tract, the caecum still contained food material and so this part of the tissue was excluded from the experiment to minimise the risk of uneaten food particulates confounding the results.

\subsection{Preparation and characterisation of silver nanomaterials and silver nitrate}

The same Ag NPs and $\mathrm{Ag}_{2} \mathrm{~S}$ NPs were used here as reported in Clark et al. (2019b) and details of the materials can be found therein. Both Ag nanomaterials were solid spherical particles (not hollow or porous) made from silver, and supplied from Applied Nanoparticles (Barcelona). The Ag NPs and $\mathrm{Ag}_{2} \mathrm{~S}$ NPs had nominal sizes of 60 and $35 \mathrm{~nm}$, respectively, and at a total $\mathrm{Ag}$ concentration of 10.8 and $14 \mathrm{~g} \mathrm{~L}^{-1}$, respectively. The Ag NP material was dispersed in $25 \mu \mathrm{M}$ tannic acid and $5.5 \mathrm{mM}$ sodium citrate, and the $\mathrm{Ag}_{2} \mathrm{~S}$ NPs were dispersed in $1 \mathrm{mg} \mathrm{mL}{ }^{-1}$ polyvinylpyrrolidone. Transmission electron microscopy showed the primary particle size (diameters of the particles in dried electron microscopy samples) for the $\mathrm{Ag}$ NPs and $\mathrm{Ag}_{2} \mathrm{~S}$ NPs to be $55 \pm 3$ and $37 \pm 19 \mathrm{~nm}$, respectively $(n=120$ and 103, respectively). The hydrodynamic diameters of ENMs in dispersions were measured by Nanoparticle Tracking Analysis (NTA, Nanosight, LM10). The hydrodynamic diameters of the Ag ENMs were made in either ultrapure water adjusted to $\mathrm{pH} 7.4$ using $0.04 \mathrm{M} \mathrm{NaOH}$, or physiological gut saline pH 7.4 (see recipe below, and NTA plots in Fig. 1) using primer plus grade nitric acid. The mean hydrodynamic diameter of the $\mathrm{Ag}$ NPs and $\mathrm{Ag}_{2} \mathrm{~S}$ NPs were $77 \pm 10$ and $123 \pm 7 \mathrm{~nm}$, respectively. In the physiological gut saline, the measured hydrodynamic diameter of the $\mathrm{Ag}$ NPs and $\mathrm{Ag}_{2} \mathrm{~S}$ NPs were $116 \pm 19$ and $134 \pm 17 \mathrm{~nm}$, respectively (Fig. 1). Further characterisation is detailed in Clark et al. (2019b).

\subsection{Gut sac preparation}

The gut sac technique used was described in Clark et al. (2019b), with minor modifications here for the physiological differences between fish and rodents. Rats were weighed and then euthanized by exposure to a rising concentration of $\mathrm{CO}_{2}$ followed by cervical dislocation; an approved Schedule 1 method, and with the entire experiment in accordance with ethical approval from the U.K. Home Office and in compliance with the European directive 2010/63/EU. The entire GIT was removed and separated into the following anatomical regions: oesophagus, stomach, duodenum, jejunum, ileum, caecum and hind intestine. Due to their large size, the intestinal regions (duodenum, jejunum, ileum and hind intestine) were dissected into smaller three inch sections to facilitate the preparation of the gut sac (Wilson and Wiseman, 1954). This approach also allowed the uniform filling of the anatomical regions of the gut to equal fullness with the test media and thus helped standardise the exposure (see below).

The gut regions were washed in a gut physiological saline (in $\mathrm{mM}$ : $\mathrm{NaCl}, 117.5 ; \mathrm{KCl}, 5.7 ; \mathrm{NaHCO}_{3}, 25.0 ; \mathrm{NaH}_{2} \mathrm{PO}_{4} . \mathrm{H}_{2} \mathrm{O}, 1.2 ; \mathrm{CaCl}_{2}, 2.5$; $\mathrm{MgSO}_{4} .7 \mathrm{H}_{2} \mathrm{O}$, 1.2; glucose, 5.0; mannitol, 23.0; $\mathrm{pH}$ 7.4) and weighed. 
A

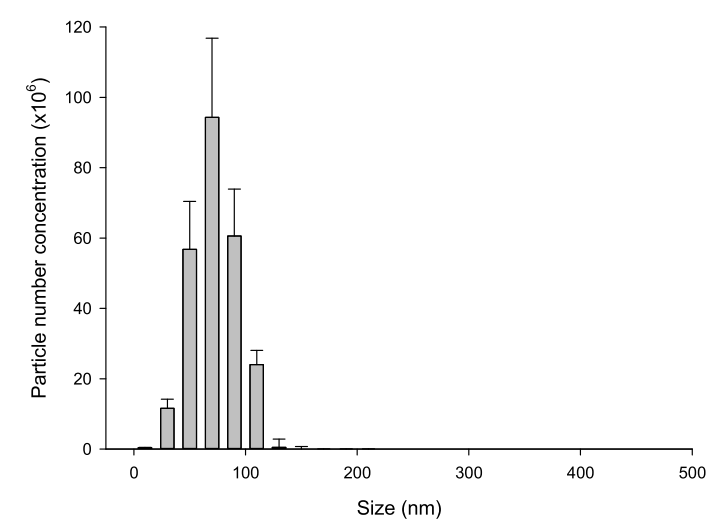

C

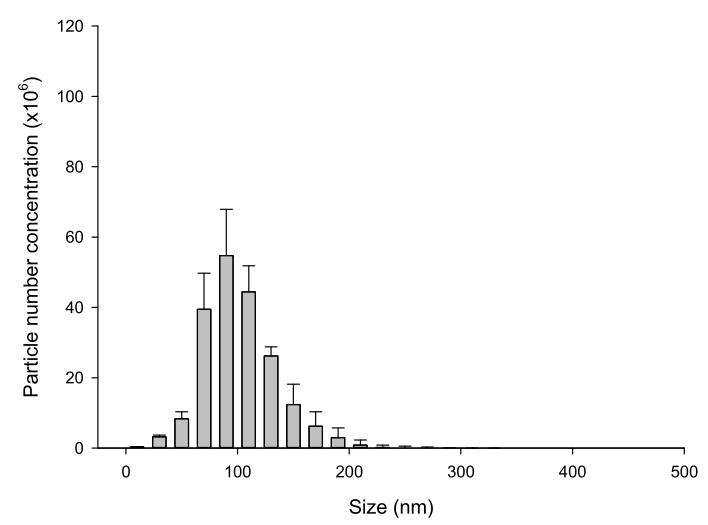

B

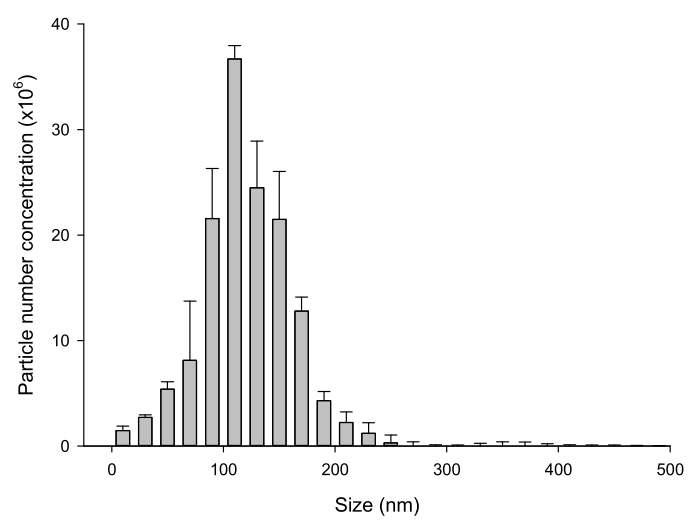

D

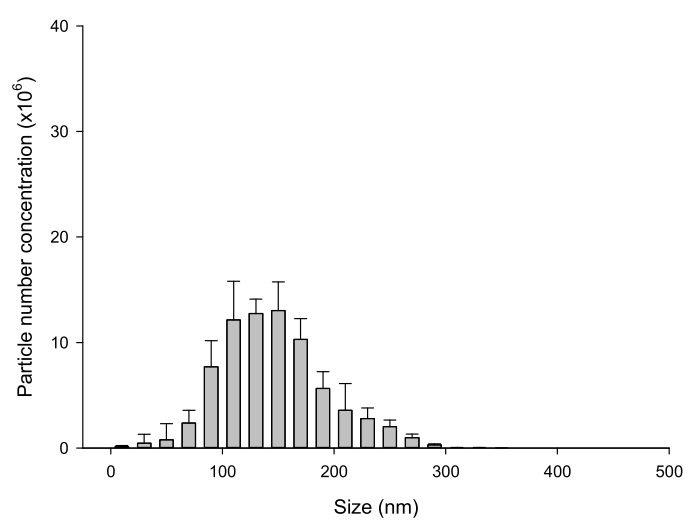

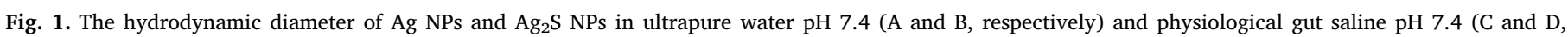

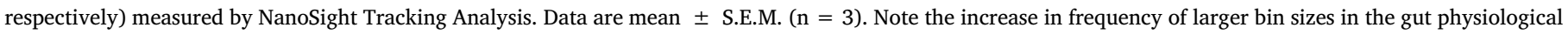
saline treatments.

Each gut sac was closed at one end using surgical suture thread and filled with the relevant saline solution containing either no added $\mathrm{Ag}$ (as above), or $1 \mathrm{mg} \mathrm{L}^{-1} \mathrm{Ag}$ as $\mathrm{AgNO}_{3}, \mathrm{Ag} \mathrm{NPs}$ or $\mathrm{Ag}_{2} \mathrm{~S}$ NPs. The silver speciation from the $\mathrm{AgNO}_{3}$ in the gut saline above (pristine, no contact with rat tissue) was theoretically calculated using Visual MINTEQ 3.1 by J. P. Gustafsson (https://vminteq.lwr.kth.se/download/). The calculated silver species in the normal gut saline containing chloride was: $\mathrm{Ag}^{+}, 0.077 \%$; $\mathrm{AgCl}$ (aq), 8.2947\%; $\mathrm{AgCl}_{2}{ }^{-}, 81.208 \%$; and $\mathrm{AgCl}_{3}{ }^{2-}$, $10.420 \%$. The sacs were subsequently closed with suture thread and weighed to calculate the volume of respective saline solution added. The gut sacs were then incubated in the gut physiological saline for $4 \mathrm{~h}$ at $37^{\circ} \mathrm{C}$.

Following the $4 \mathrm{~h}$ incubation, the gut sacs were removed and weighed for fluid flux calculations according to Clark et al. (2019b). Then, the gut sacs were carefully cut open and rinsed into $5 \mathrm{~mL}$ of clean gut physiological saline to collect the luminal contents. Tissues were then rinsed in a second $5 \mathrm{~mL}$ of solution containing gut physiological saline with $1 \mathrm{mM}$ EDTA and blotted with $25 \mathrm{~cm}^{2}$ pieces of tissue paper ( 4 pieces for the stomach and 2 for the oesophagus and intestinal regions) to remove surface bound material $[<5 \%$ adsorbed; see surface binding experiment in Clark et al. (2019b)]. This blotting paper was kept in the EDTA rinse and processed as described below. The rinse solutions were frozen at $-20{ }^{\circ} \mathrm{C}$ until processing for metal analysis. Following the rinse solutions, the mucosa was separated from the muscularis by using a glass microscope slide, both parts of the tissue were weighed and stored at $-20^{\circ} \mathrm{C}$. The tissues were then freeze dried and reweighed before acid digestion for total $\mathrm{Ag}$ and electrolyte analysis (see below).

\subsection{Total Ag, $\mathrm{Na}$ and $\mathrm{K}$ analysis}

Analysis of the luminal saline, EDTA rinse solutions, and tissues were performed according to Clark et al. (2019b). Briefly, the samples were thawed, acidified with $2 \mathrm{~mL}$ of primer plus grade nitric acid, diluted with ultrapure water (containing internal standards of indium and iridium) to $20 \mathrm{~mL}$ and left over night before analysing for total $\mathrm{Ag}$ concentration using an ICP-MS (iCAP RQ Thermo Fisher). All samples were analysed using matrix matched standards and procedural blanks to account for trace elements from tubes and reagents. For the tissues, each piece of tissue was digested in $0.2 \mathrm{~mL}$ of analytical grade nitric acid $\left(0.5 \mathrm{~mL}\right.$ for the muscularis of the stomach) and incubated at $60{ }^{\circ} \mathrm{C}$ for $4 \mathrm{~h}$. The tissues were then diluted to a final volume of $2 \mathrm{~mL}(3 \mathrm{~mL}$ for the muscularis of the stomach) with $22.2 \mu \mathrm{g} \mathrm{L}{ }^{-1}$ indium and iridium spiked ultrapure water. The limit of detection for total Ag of the ICP-MS was around $0.2 \mathrm{ng} \mathrm{mL}^{-1}$ of tissue digest, which equates to around $10.6 \mathrm{ng} \mathrm{g}^{-1}$ dry weight (dw) of tissue. The $\mathrm{Na}^{+}$and $\mathrm{K}^{+}$concentrations were also measured in the tissue digests. Following Ag analysis, $0.5 \mathrm{~mL}$ of the sample was taken and diluted to $2.5 \mathrm{~mL}$ using yttrium (internal standard) spiked ultrapure water and analysed using an iCAP 7000 ICPOES for $\mathrm{Na}^{+}$and $\mathrm{K}^{+}$.

\subsection{Statistical analysis}

All data are presented as mean \pm S.E.M., unless otherwise stated. Graphs are presented and statistical analysis conducted in SigmaPlot 13.0. Data ( $n=5 / 6$ gut sacs per treatment) was analysed for outliers using Grubbs test. Data were check for normality (Shapiro-Wilk test) 
Table 1

Mass of Ag (total in $\mathrm{ng}$ ) found in the luminal saline (rinse 1) and EDTA wash (rinse 2) to confirm exposure of the rodent gut sacs.

\begin{tabular}{|c|c|c|c|c|c|c|c|}
\hline Treatment & Sample type & Oesophagus & Stomach & Duodenum & Jejunum & Ileum & Hind intestine \\
\hline \multirow[t]{2}{*}{ Control } & Luminal saline & $<10.4$ & $<10.4$ & $<10.4$ & $<10.4$ & $<10.4$ & $<10.4$ \\
\hline & EDTA wash & $<10.4$ & $<10.4$ & $<10.4$ & $<10.4$ & $<10.4$ & $<10.4$ \\
\hline \multirow[t]{2}{*}{$\mathrm{AgNO}_{3}$} & Luminal saline & $46.1 \pm 12.6^{\mathrm{Aa}}$ & $160.5 \pm 52.2^{\mathrm{Aa}}$ & $132.2 \pm 15.4^{\mathrm{Aa}}$ & $207.3 \pm 36.7^{\mathrm{Aa}}$ & $137.1 \pm 32.6^{\mathrm{Aa}}$ & $283.3 \pm 34.4^{\mathrm{Aa}}$ \\
\hline & EDTA wash & $14.4 \pm 1.2^{\mathrm{Aa}}$ & $60.6 \pm 15.5^{\mathrm{Aa}}$ & $36.2 \pm 3.9^{\mathrm{Aa}}$ & $46.2 \pm 7.1^{\mathrm{Aa}}$ & $40.6 \pm 8.2^{\mathrm{Aa}}$ & $49.0 \pm 5.7^{\mathrm{Aa}}$ \\
\hline \multirow[t]{2}{*}{ Ag NPs } & Luminal saline & $39.9 \pm 5.0^{\mathrm{Aa}}$ & $287.5 \pm 95.2^{\mathrm{Ac}}$ & $128.7 \pm 19.0^{\mathrm{Abc}}$ & $186.2 \pm 39.0^{\mathrm{Ac}}$ & $74.8 \pm 15.9^{\text {Aab }}$ & $199.9 \pm 45.3^{\mathrm{Ac}}$ \\
\hline & EDTA wash & $15.0 \pm 3.0^{\mathrm{Ba}}$ & $51.9 \pm 14.5^{\mathrm{Bb}}$ & $27.3 \pm 1.3^{\mathrm{Bab}}$ & $35.9 \pm 4.1^{\mathrm{Bb}}$ & $22.9 \pm 1.4^{\mathrm{Bab}}$ & $33.0 \pm 5.5^{\mathrm{Bab}}$ \\
\hline \multirow[t]{2}{*}{$\mathrm{Ag}_{2} \mathrm{~S}$ NPs } & Luminal saline & $19.0 \pm 2.8^{\mathrm{Aa}}$ & $162.8 \pm 55.0^{\mathrm{Aa}}$ & $87.7 \pm 19.4^{\mathrm{Aa}}$ & $100.6 \pm 34.9^{\mathrm{Aa}}$ & $60.2 \pm 16.5^{\mathrm{Aa}}$ & $136.2 \pm 38.7^{\mathrm{Aa}}$ \\
\hline & EDTA wash & $15.4 \pm 0.8^{\mathrm{Aa}}$ & $37.0 \pm 6.6^{\mathrm{Aa}}$ & $23.3 \pm 2.2^{\mathrm{Aa}}$ & $26.8 \pm 4.3^{\mathrm{Aa}}$ & $28.6 \pm 5.9^{\mathrm{Aa}}$ & $25.7 \pm 4.9^{\mathrm{Aa}}$ \\
\hline
\end{tabular}

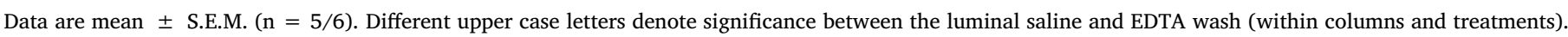

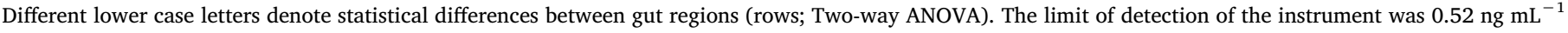
which equates to $10.4 \mathrm{ng} \mathrm{Ag}$ in the luminal and EDTA washes.

and equal variance (Brown Forsythe). Data that were normally distributed, or could be $\log _{10}$ transformed to become normally distributed, were analysed by either a one-way ANOVA or two-way ANOVA, and subsequently checked with a Holm-Sidak post hoc test. Where data were not parametric, the Kruskal-Wallis test was used and a Tukey's or Dunns post hoc test.

\section{Results}

\subsection{Ag exposure of gut sacs}

Following the $4 \mathrm{~h}$ exposure, the gut sacs were cut open and the contents collected for total Ag analysis. This was followed by an EDTA wash to ensure loosely bound $\mathrm{Ag}$ was removed from the surface of the mucosa. The presence of $\mathrm{Ag}$ in these washes confirmed that the $\mathrm{Ag}$ was in excess throughout the exposure and ensured that any apparent accumulation by the tissue was not limited by the supply of $\mathrm{Ag}$ in the lumen. As expected, most of the Ag was labile and within the first luminal rinse, although some total Ag was also removed by the EDTA wash (Table 1).

The washes from the control gut sacs contained no detectable $\mathrm{Ag}$ (Table 1). Within the $\mathrm{AgNO}_{3}$ treatment, the absolute mass of $\mathrm{Ag}$ in the luminal wash ranged from 40 to $300 \mathrm{ng}$, depending on the gut region. The highest absolute mass of $\mathrm{Ag}$ was in the luminal rinse of the jejunum and hind intestine which was 2.5 -fold higher compared to the luminal rinse from the oesophagus, although this was not statistically elevated compared to other gut regions. The pattern of $\mathrm{Ag}$ content in the washings from both the $\mathrm{Ag} \mathrm{NP}$ and $\mathrm{Ag}_{2} \mathrm{~S}$ NP treatments were similar to the $\mathrm{AgNO}_{3}$ treatment; with the absolute mass of $\mathrm{Ag}$ in the luminal washes between 20 and $300 \mathrm{ng}$ for the nanomaterials. Within the luminal rinse of the Ag NP treatment, there was significantly more Ag associated with the rinses from the stomach, jejunum and hind intestine (all values $P<0.001$ ) compared to the oesophagus. Similarly, within the $\mathrm{Ag}_{2} \mathrm{~S}$ NP treatment there was a trend for the stomach, jejunum and hind intestine have more Ag compared to the oesophagus, but there was no statistical difference between gut regions.

There were also some differences in the residual $\mathrm{Ag}$ in the EDTA wash (Table 1). In the $\mathrm{AgNO}_{3}$ treatment, there was no significant difference between gut regions, but the tendency was to have higher concentrations in the EDTA wash associated with the intestinal regions. In the EDTA wash from the Ag NP treatment, the most total Ag was associated with the stomach $(P=0.003)$ and jejunum $(P=0.029)$ compared to the oesophagus. There was no significant difference between the gut regions in the $\mathrm{Ag}$ in the EDTA wash of the $\mathrm{Ag}_{2} \mathrm{~S}$ NP treatment.

The exposure was also confirmed by the measured concentrations of total Ag in the gut tissues (Table 2). The control tissues (both mucosa and muscularis) contained no detectable $\mathrm{Ag}$, regardless of gut region $\left(\mathrm{LOD}=10.6 \mathrm{ng} \mathrm{g}^{-1} \mathrm{dw}\right)$. Within the Ag treatments there was some material-type and gut region effects on the concentration of total $\mathrm{Ag}$ found in the mucosa following exposure. Within the $\mathrm{AgNO}_{3}$ treatment, the duodenum $(P=0.006)$, jejunum $(P<0.001)$, ileum $(P=0.002)$ and hind intestine $(P=0.017)$ all had significantly higher total Ag concentrations compared to the stomach. For example, the intestinal regions contained 7-12 fold higher Ag compared to the stomach ( $\left.\sim 640 \mathrm{ng} \mathrm{g}^{-1} \mathrm{dw}\right)$. Similar observations were made by anatomical region of the gut within the $\mathrm{Ag} \mathrm{NP}$ and $\mathrm{Ag}_{2} \mathrm{~S} \mathrm{NP}$ treatment, with the jejunum $(P<0.001$ and $P<0.001$, respectively $)$ and ileum $(P<0.001$ and $P=0.003$, respectively) being significantly higher compared to the stomach. Between the $\mathrm{Ag}$ treatments, there was very little difference except the hind intestine of the $\mathrm{Ag}_{2} \mathrm{~S} \mathrm{NP}$ treatment which contained around a third of the $\mathrm{Ag}$ compared to the $\mathrm{AgNO}_{3}$ treatment $\left(\sim 3600 \mathrm{ng} \mathrm{g}^{-1} \mathrm{dw}\right)$. Between the nanomaterials, there was no significant difference in the total $\mathrm{Ag}$ concentration within the mucosa.

There were statistical differences by both treatment and gut region with respect to the concentration of total $\mathrm{Ag}$ in the muscularis. In all the $\mathrm{Ag}$ treatments, the four anatomical regions of the intestine were significantly elevated compared to the stomach. For example, in the $\mathrm{AgNO}_{3}$ treatment, the muscularis of the stomach contained around $100 \mathrm{ng} \mathrm{g}^{-1} \mathrm{dw}$ whereas the intestinal regions ranged from 600 to $3500 \mathrm{ng} \mathrm{g}^{-1} \mathrm{dw}$ (all values $P<0.001$ ). Additionally, between treatments, the stomach, duodenum, jejunum, ileum and hind intestine (all values $P<0.001$ ) were all significantly elevated compared to their respective gut regions from both the $\mathrm{Ag} \mathrm{NPs}$ and $\mathrm{Ag}_{2} \mathrm{~S}$ NPs treatments. For example, the duodenum of the $\mathrm{AgNO}_{3}, \mathrm{Ag} \mathrm{NP}$ and $\mathrm{Ag}_{2} \mathrm{~S}$ NP treatments contained around 2500, 900 and $1400 \mathrm{ng} \mathrm{g}^{-1} \mathrm{dw}$, respectively. The only exception was the muscularis of the oesophagus where the total $\mathrm{Ag}$ concentration in the tissue were the same for the $\mathrm{AgNO}_{3}$ treatment compared to both the $\mathrm{Ag} \mathrm{NP}$ and $\mathrm{Ag}_{2} \mathrm{~S}$ NP treatments. The only effect between nanomaterials was observed in the jejunum where the $\mathrm{Ag}_{2} \mathrm{~S} \mathrm{NP}$ treatment had around half the total $\mathrm{Ag}$ concentration compared to the Ag NPs treatment (the latter $685 \mathrm{ng} \mathrm{g}^{-1} \mathrm{dw}$, $P=0.021$ ).

Table 2 also shows the transepithelial accumulation of total $\mathrm{Ag}$ across the gut into the serosal compartment. Only a few regions of the gut showed the ability for transepithelial accumulation of $\mathrm{Ag}$ and they were limited to the $\mathrm{AgNO}_{3}$ and $\mathrm{Ag} \mathrm{NP}$ treatments. In the $\mathrm{AgNO}_{3}$ treatment, the duodenum, jejunum, ileum and hind intestine showed transepithelial accumulation of total $\mathrm{Ag}$, with there being significantly more in the serosal saline from the duodenum $(P=0.005)$, jejunum $(P=0.038)$ and ileum $(P=0.017)$ compared to that from the hind intestine. The only gut region to show transepithelial accumulation in the Ag NP treatment was the duodenum with the serosal saline having a significantly lower total $\mathrm{Ag}$ concentration compared to the same region of the $\mathrm{AgNO}_{3}$ treatment $(P=0.043)$. There was no evidence of transepithelial accumulation of total $\mathrm{Ag}$ into the serosal saline of the $\mathrm{Ag}_{2} \mathrm{~S}$ NP treatment. 
Table 2

The concentration of total $\mathrm{Ag}$ in the tissues and the serosal saline of gut sacs from rodents after $4 \mathrm{~h}$ of exposure.

\begin{tabular}{|c|c|c|c|c|c|c|c|}
\hline $\begin{array}{l}\text { Treatme- } \\
\text { nt }\end{array}$ & Sample type & Oesophagus & Stomach & Duodenum & Jejunum & Ileum & Hind intestine \\
\hline \multirow[t]{4}{*}{ Control } & Mucosa (ng g $\left.{ }^{-1}\right)$ & $<10.6$ & $<10.6$ & $<10.6$ & $<10.6$ & $<10.6$ & $<10.6$ \\
\hline & Muscularis (ng g ${ }^{-1}$ ) & $<10.6$ & $<10.6$ & $<10.6$ & $<10.6$ & $<10.6$ & $<10.6$ \\
\hline & $\%$ in mucosa & N/A & N/A & $\mathrm{N} / \mathrm{A}$ & $\mathrm{N} / \mathrm{A}$ & N/A & N/A \\
\hline & Serosal concentration ( $\mathrm{ng} \mathrm{mL}^{-1}$ ) & $<1.25$ & $<1.25$ & $<1.25$ & $<1.25$ & $<1.25$ & $<1.25$ \\
\hline \multirow[t]{4}{*}{$\mathrm{AgNO}_{3}$} & Mucosa (ng $g^{-1}$ ) & $3055.8 \pm 968.0^{\mathrm{Aab}}$ & $638.6 \pm 128.3^{\mathrm{Aa}}$ & $4282.4 \pm 574.6^{\mathrm{Ab}}$ & $7087.2 \pm 1650.5^{\mathrm{Ab}}$ & $6431.0 \pm 1700.5^{\mathrm{Ab}}$ & $3639.5 \pm 631.9^{\mathrm{Ab}}$ \\
\hline & Muscularis (ng g ${ }^{-1}$ ) & $1045.3 \pm 324.9^{\mathrm{Aab}}$ & $112.1 \pm 31.0^{\mathrm{Ac}}$ & $2513.8 \pm 267.2^{\mathrm{Ad}}$ & $3577.6 \pm 644.9^{\mathrm{Ad}}$ & $2584.1 \pm 553.1^{\mathrm{Aad}}$ & $638.4 \pm 77.6^{\mathrm{Ab}}$ \\
\hline & $\%$ in mucosa & $48.1 \pm 11.5^{\mathrm{Aa}}$ & $47.7 \pm 4.8^{\mathrm{Aa}}$ & $41.0 \pm 3.5^{\mathrm{Aa}}$ & $47.5 \pm 3.0^{\mathrm{Aa}}$ & $48.2 \pm 8.0^{\mathrm{Aa}}$ & $57.7 \pm 7.4^{\mathrm{Aa}}$ \\
\hline & Serosal concentration ( $\mathrm{ng} \mathrm{mL}^{-1}$ ) & $<1.25$ & $<1.25$ & $10.4 \pm 2.5^{\mathrm{Aa}}$ & $7.6 \pm 2.7^{\mathrm{a}}$ & $8.1 \pm 1.4^{\mathrm{a}}$ & $2.1 \pm 0.6^{\mathrm{b}}$ \\
\hline \multirow[t]{4}{*}{ Ag NPs } & Mucosa (ng $g^{-1}$ ) & $1313.8 \pm 486.8^{\mathrm{Aab}}$ & $369.4 \pm 116.8^{\mathrm{Aa}}$ & $1730.5 \pm 462.9^{\mathrm{Aab}}$ & $3635.7 \pm 1246.7^{\mathrm{Ab}}$ & $5364.8 \pm 1500.6^{\mathrm{Ab}}$ & $2189.3 \pm 394.5^{\mathrm{ABb}}$ \\
\hline & Muscularis (ng g ${ }^{-1}$ ) & $407.9 \pm 123.4^{\mathrm{Aa}}$ & $20.3 \pm 5.1^{\mathrm{Bb}}$ & $906.6 \pm 284.1^{\mathrm{Bc}}$ & $685.0 \pm 120.0^{\mathrm{Bc}}$ & $599.1 \pm 152.7^{\mathrm{Bc}}$ & $131.8 \pm 35.8^{\mathrm{Ba}}$ \\
\hline & $\%$ in mucosa & $51.9 \pm 8.2^{\mathrm{Aa}}$ & $69.3 \pm 4.3^{\mathrm{Aa}}$ & $60.8 \pm 4.0^{\mathrm{Aa}}$ & $71.3 \pm 3.0^{\mathrm{Aa}}$ & $67.8 \pm 8.2^{\mathrm{Aa}}$ & $70.6 \pm 4.7^{\mathrm{Aa}}$ \\
\hline & Serosal concentration (ng $\mathrm{mL}^{-1}$ ) & $<1.25$ & $<1.25$ & $2.7 \pm 1.0^{\mathrm{B}}$ & $<1.25$ & $<1.25$ & $<1.25$ \\
\hline \multirow[t]{4}{*}{$\mathrm{Ag}_{2} \mathrm{~S}$ NPs } & Mucosa $\left(n g^{-1}\right)$ & $3972.7 \pm 1387.2^{\mathrm{Aa}}$ & $313.6 \pm 89.9^{\mathrm{Ab}}$ & $2613.4 \pm 1843.3^{\mathrm{Aa}}$ & $3174.2 \pm 1099.2^{\mathrm{Aa}}$ & $2534.2 \pm 539.6^{\mathrm{Aa}}$ & $1278.2 \pm 379.2^{\text {Bab }}$ \\
\hline & Muscularis (ng g ${ }^{-1}$ ) & $705.8 \pm 141.4^{\mathrm{Aab}}$ & $32.5 \pm 12.9^{\mathrm{Bd}}$ & $1482.2 \pm 668.0^{\mathrm{Ba}}$ & $278.8 \pm 66.1^{\mathrm{Cbc}}$ & $336.3 \pm 88.1^{\mathrm{Bbc}}$ & $141.2 \pm 52.6^{\mathrm{Bc}}$ \\
\hline & $\%$ in mucosa & $29.8 \pm 12.7^{\mathrm{Aa}}$ & $64.5 \pm 8.2^{\mathrm{Aab}}$ & $57.3 \pm 4.1^{\mathrm{Aab}}$ & $83.9 \pm 2.9^{\mathrm{Ab}}$ & $83.4 \pm 3.2^{\mathrm{Ab}}$ & $70.5 \pm 10.4^{\mathrm{Aab}}$ \\
\hline & Serosal concentration (ng $\mathrm{mL}^{-1}$ ) & $<1.25$ & $<1.25$ & $<1.25$ & $<1.25$ & $<1.25$ & $<1.25$ \\
\hline
\end{tabular}

Data are mean \pm S.E.M. $(n=5 / 6)$. Total Ag concentrations are expressed as $\mathrm{ng} \mathrm{g}^{-1}$ dry weight. Different upper case letters denote significant difference between treatments for the same sample type (two-way ANOVA, columns). Lower case letters denote difference between gut regions within treatments (two-way ANOVA, rows). The limit of detection of the instrument was $0.17 \mathrm{ng} \mathrm{mL}^{-1}$ which equates to $10.6 \mathrm{ng} \mathrm{g}^{-1}$ in tissue samples. The limit of detection for the serosal solution was $0.25 \mathrm{ng} \mathrm{mL}^{-1}$ which equates to $1.25 \mathrm{ng} \mathrm{mL}^{-1}$.

\subsection{Partitioning of Ag dose in the gut sacs}

The percentage of the original exposure dose found in each compartment of the gut sac preparations is shown in Table 3. The luminal rinse contained $67 \%$ or more of the total $\mathrm{Ag}$ in the gut sacs, and demonstrates the different materials were not in limiting supply (Table 3 ). In the case of the EDTA wash, there was no treatment related differences in percent of $\mathrm{Ag}$ association, but some changes in gut regions of the $\mathrm{Ag}$ NPs and $\mathrm{Ag}_{2} \mathrm{~S}$ NPs, but not $\mathrm{AgNO}_{3}$ treatment, were observed. For example, in both nano Ag treatments, there was significantly less percent $\mathrm{Ag}$ associated with the EDTA wash of the hind intestine compared to the oesophagus (Table 3). Regardless, the luminal and EDTA washes were sufficient enough to remove excess Ag, leaving only a few percent in the tissues. Interestingly, the transepithelial accumulation of $\mathrm{Ag}$ as $\mathrm{AgNO}_{3}$ exceeded the percent of the dose found in the duodenum mucosa $(P<0.001)$ and muscularis $(P=0.007)$. This effect was not observed in the $\mathrm{Ag} \mathrm{NP}$ or $\mathrm{Ag}_{2} \mathrm{~S}$ NP treatments.

\subsection{Tissue fluid flux, moisture and electrolyte composition}

There was no treatment-related effects in the fluid flux (Table 4) or tissue moisture (data not shown). There were some significant changes in the tissue electrolyte composition (Table 4). Throughout the gastrointestinal tract, the $\mathrm{Na}^{+}$concentration ranged from 400 to $1000 \mu \mathrm{mol} \mathrm{g}^{-1} \mathrm{dw}$, depending on gut region, and did not significantly alter between treatments. However, there were some significant changes in the tissue $\mathrm{K}^{+}$concentration. In general, the Ag NP treatment had a more variable $\mathrm{K}^{+}$concentration which resulted in some significant differences compared to other treatments. For example, the $\mathrm{K}^{+}$ concentration in the duodenum of the Ag NP treatment was around

Table 3

Partitioning of Ag distribution throughout the gut sac. The luminal rinse, EDTA wash, the mucosa and muscularis expressed as the percentage of Ag dosed at the start of the $4 \mathrm{~h}$ incubation.

\begin{tabular}{|c|c|c|c|c|c|c|}
\hline Treatment & Region of gut & Luminal rinse & EDTA wash & Mucosa & Muscularis & Serosal \\
\hline \multirow[t]{6}{*}{$\mathrm{AgNO}_{3}$} & Oesophagus & $82.2 \pm 2.0^{\mathrm{Aa}}$ & $9.7 \pm 1.0^{\mathrm{Aa} *}$ & $3.5 \pm 1.0^{\mathrm{Aab}_{* \#}}$ & $4.7 \pm 1.7^{\mathrm{Aab}_{*}}$ & N/D \\
\hline & Stomach & $88.9 \pm 3.8^{\mathrm{Aa}}$ & $8.8 \pm 3.7^{\mathrm{Aa}}$ & $1.1 \pm 0.2^{\mathrm{Aa} *}$ & $1.2 \pm 0.2^{\mathrm{Aa} *}$ & $\mathrm{~N} / \mathrm{D}$ \\
\hline & Duodenum & $77.5 \pm 2.1^{\mathrm{Aa}}$ & $5.6 \pm 0.7^{\mathrm{Aa} *}$ & $3.0 \pm 0.6^{\mathrm{Aab} * \#^{\wedge}}$ & $4.3 \pm 0.4^{\mathrm{Ab} *}$ & $9.7 \pm 1.5^{\mathrm{Aab} *}$ \\
\hline & Jejunum & $73.9 \pm 4.1^{\mathrm{Aa}}$ & $6.6 \pm 1.1^{\mathrm{Aa} *}$ & $4.8 \pm 1.7^{\mathrm{Aab}_{*}}$ & $5.1 \pm 1.0^{\mathrm{Ab} *}$ & $9.6 \pm 3.1^{\mathrm{ab} *}$ \\
\hline & Ileum & $67.3 \pm 5.1^{\mathrm{Aa}}$ & $10.6 \pm 2.7^{\mathrm{Aa}}$ & $3.8 \pm 1.1^{\mathrm{Aab} *}$ & $3.9 \pm 1.1^{\mathrm{Aab}_{*}}$ & $14.4 \pm 1.9^{\mathrm{a}}$ \\
\hline & Hind intestine & $84.4 \pm 2.6^{\mathrm{Aa}}$ & $5.2 \pm 0.7^{\mathrm{Aa}}$ & $5.6 \pm 2.0^{\mathrm{Ab} *}$ & $3.2 \pm 0.6^{\mathrm{Aab}_{*}}$ & $1.6 \pm 0.4^{\mathrm{b}}$ \\
\hline \multirow[t]{6}{*}{ Ag NPs } & Oesophagus & $80.8 \pm 1.9^{\mathrm{Aa}}$ & $14.4 \pm 1.2^{\mathrm{Aab}}$ & $2.6 \pm 0.7^{\mathrm{ABab} *}$ & $2.2 \pm 0.6^{\mathrm{Aa} *}$ & N/D \\
\hline & Stomach & $91.6 \pm 1.1^{\mathrm{Aa}}$ & $7.1 \pm 0.9^{\mathrm{Aabc}}$ & $1.0 \pm 0.2^{\mathrm{Aa} *}$ & $0.4 \pm 0.0^{\mathrm{Bb} * \#}$ & $\mathrm{~N} / \mathrm{D}$ \\
\hline & Duodenum & $78.3 \pm 2.5^{\mathrm{Aa}}$ & $8.9 \pm 0.9^{\mathrm{Aabc}}$ & $3.5 \pm 0.4^{\mathrm{Ab} *}$ & $2.2 \pm 0.4^{\mathrm{Aa} *}$ & $7.2 \pm 2.0^{\mathrm{A}}$ \\
\hline & Jejunum & $88.2 \pm 0.8^{\mathrm{Aa}}$ & $6.8 \pm 0.9^{\mathrm{Ac}}$ & $3.5 \pm 0.4^{\mathrm{Ab} *}$ & $1.4 \pm 0.2^{\mathrm{Ba} * \#}$ & N/D \\
\hline & Ileum & $80.1 \pm 5.2^{\mathrm{Aa}}$ & $13.5 \pm 4.1^{\mathrm{Aab}}$ & $4.9 \pm 1.6^{\mathrm{Ab} *}$ & $1.5 \pm 0.3^{\mathrm{Ba} *}$ & N/D \\
\hline & Hind intestine & $91.2 \pm 1.9^{\mathrm{Aa}}$ & $4.7 \pm 1.0^{\mathrm{Ac}}$ & $2.7 \pm 0.9^{\mathrm{ABab}_{*}}$ & $1.4 \pm 0.7^{\mathrm{Bab} *}$ & N/D \\
\hline \multirow[t]{6}{*}{$\mathrm{Ag}_{2} \mathrm{~S} \mathrm{NPs}$} & Oesophagus & $83.1 \pm 1.7^{\mathrm{Aa}}$ & $12.0 \pm 1.5^{\mathrm{Aa} *}$ & $1.3 \pm 0.6^{\mathrm{Ba} \# \#}$ & $3.6 \pm 1.0^{\mathrm{Aa} * \#}$ & N/D \\
\hline & Stomach & $94.4 \pm 0.7^{\mathrm{Ba}}$ & $4.2 \pm 0.6^{\mathrm{Abc} *}$ & $1.0 \pm 0.3^{\mathrm{Aa} * \#}$ & $0.5 \pm 0.1^{\mathrm{Bb} \# \#}$ & N/D \\
\hline & Duodenum & $87.6 \pm 3.5^{\mathrm{Aa}}$ & $6.5 \pm 1.5^{\mathrm{Aab}}$ & $3.2 \pm 1.0^{\mathrm{Aa} *}$ & $2.7 \pm 1.2^{\mathrm{Aa} *}$ & N/D \\
\hline & Jejunum & $92.4 \pm 1.3^{\mathrm{Aa}}$ & $4.1 \pm 0.6^{\mathrm{Abc}}$ & $3.0 \pm 0.9^{\mathrm{Aa}}$ & $0.4 \pm 0.1^{\mathrm{Cb} *}$ & N/D \\
\hline & Ileum & $88.3 \pm 1.9^{\mathrm{Aa}}$ & $8.7 \pm 1.8^{\mathrm{Aac}_{*}}$ & $2.5 \pm 0.2^{\mathrm{Aa} * \#}$ & $0.5 \pm 0.1^{\mathrm{Cb} * \#}$ & N/D \\
\hline & Hind intestine & $94.9 \pm 0.9^{\mathrm{Aa}}$ & $3.4 \pm 0.9^{\mathrm{Ab} *}$ & $1.3 \pm 0.4^{\mathrm{Ba} *}$ & $0.4 \pm 0.1^{\mathrm{Cb} * \#}$ & N/D \\
\hline
\end{tabular}

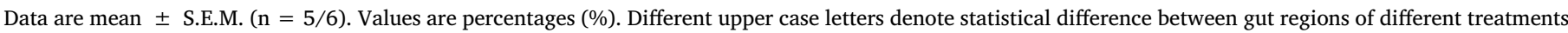

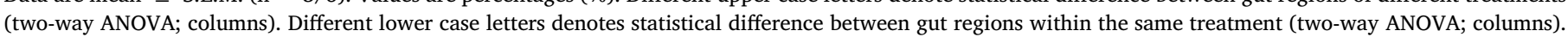

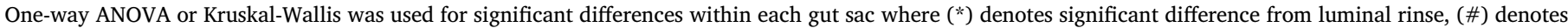

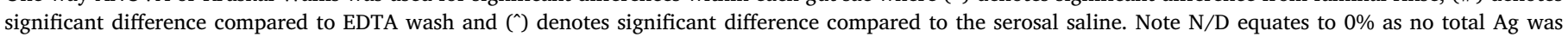
detected - the statistical notation included is only for positive values for clarity. 
Table 4

Fluid flux, accumulation rate of total Ag into the mucosa and tissue electrolyte concentration in the rodent gut sac.

\begin{tabular}{|c|c|c|c|c|c|c|c|}
\hline Measurement & Treatment & Oesophagus & Stomach & Duodenum & Jejunum & Ileum & Hind intestine \\
\hline \multirow[t]{4}{*}{ Fluid flux $\left(m L g^{-1} h^{-1}\right)$} & Control & $0.01 \pm 0.02^{\mathrm{A}}$ & $0.00 \pm 0.01^{\mathrm{A}}$ & $0.06 \pm 0.02^{\mathrm{A}}$ & $0.00 \pm 0.01^{\mathrm{A}}$ & $0.03 \pm 0.01^{\mathrm{A}}$ & $0.00 \pm 0.00^{\mathrm{A}}$ \\
\hline & $\mathrm{AgNO}_{3}$ & $-0.02 \pm 0.00^{\mathrm{A}}$ & $0.00 \pm 0.00^{\mathrm{A}}$ & $0.03 \pm 0.01^{\mathrm{A}}$ & $-0.02 \pm 0.03^{\mathrm{A}}$ & $0.00 \pm 0.03^{\mathrm{A}}$ & $-0.01 \pm 0.00^{\mathrm{A}}$ \\
\hline & $\mathrm{Ag}$ NPs & $-0.01 \pm 0.00^{\mathrm{A}}$ & $-0.01 \pm 0.00^{\mathrm{A}}$ & $0.01 \pm 0.01^{\mathrm{A}}$ & $-0.03 \pm 0.02^{\mathrm{A}}$ & $0.00 \pm 0.01^{\mathrm{A}}$ & $-0.01 \pm 0.00^{\mathrm{A}}$ \\
\hline & $\mathrm{Ag}_{2} \mathrm{~S}$ NPs & $-0.01 \pm 0.00^{\mathrm{A}}$ & $-0.01 \pm 0.00^{\mathrm{A}}$ & $0.03 \pm 0.02^{\mathrm{A}}$ & $0.00 \pm 0.01^{\mathrm{A}}$ & $0.03 \pm 0.01^{\mathrm{A}}$ & $-0.01 \pm 0.01^{\mathrm{A}}$ \\
\hline \multirow[t]{4}{*}{$\mathrm{Ag}$ accumulation rate into mucosa $\left(\mathrm{nmol} \mathrm{g}^{-1} \mathrm{~h}^{-1}\right)$} & Control & N/A & N/A & $\mathrm{N} / \mathrm{A}$ & $\mathrm{N} / \mathrm{A}$ & N/A & N/A \\
\hline & $\mathrm{AgNO}_{3}$ & $7.1 \pm 2.3^{\text {Aab }}$ & $1.5 \pm 0.3^{\mathrm{Aab}}$ & $10.0 \pm 1.3^{\mathrm{Ab}}$ & $16.6 \pm 3.9^{\mathrm{Ab}}$ & $15.0 \pm 4.0^{\mathrm{Ab}}$ & $8.5 \pm 1.5^{\mathrm{Ab}}$ \\
\hline & $\mathrm{Ag}$ NPs & $3.1 \pm 1.1^{\mathrm{Aab}}$ & $0.9 \pm 0.3^{\mathrm{Aa}}$ & $4.0 \pm 1.1^{\mathrm{Aab}}$ & $8.5 \pm 2.9^{\mathrm{Ab}}$ & $12.5 \pm 3.5^{\mathrm{Ab}}$ & $5.1 \pm 0.9^{\mathrm{ABb}}$ \\
\hline & $\mathrm{Ag}_{2} \mathrm{~S}$ NPs & $9.3 \pm 3.2^{\mathrm{Aa}}$ & $0.7 \pm 0.2^{\mathrm{Ab}}$ & $6.1 \pm 4.3^{\mathrm{Aa}}$ & $7.4 \pm 2.3^{\mathrm{Aa}}$ & $5.0 \pm 1.2^{\mathrm{Aa}}$ & $3.0 \pm 0.9^{\mathrm{Bab}}$ \\
\hline \multirow[t]{4}{*}{ Na concentration $\left(\mu \mathrm{mol} \mathrm{g}{ }^{-1} \mathrm{dw}\right)$} & Control & $514 \pm 35^{\mathrm{A}}$ & $566 \pm 32^{\mathrm{A}}$ & $1035 \pm 98^{\mathrm{A}}$ & $940 \pm 110^{\mathrm{A}}$ & $1031 \pm 134^{\mathrm{A}}$ & $607 \pm 46^{\mathrm{A}}$ \\
\hline & $\mathrm{AgNO}_{3}$ & $482 \pm 34^{\mathrm{A}}$ & $491 \pm 52^{\mathrm{A}}$ & $883 \pm 170^{\mathrm{A}}$ & $1048 \pm 189^{\mathrm{A}}$ & $896 \pm 185^{\mathrm{A}}$ & $634 \pm 72^{\mathrm{A}}$ \\
\hline & Ag NPs & $620 \pm 49^{\mathrm{A}}$ & $501 \pm 27^{\mathrm{A}}$ & $743 \pm 89^{\mathrm{A}}$ & $857 \pm 75^{\mathrm{A}}$ & $1066 \pm 183^{A}$ & $720 \pm 59^{\mathrm{A}}$ \\
\hline & $\mathrm{Ag}_{2} \mathrm{~S}$ NPs & $532 \pm 77^{\mathrm{A}}$ & $408 \pm 121^{\mathrm{A}}$ & $976 \pm 210^{\mathrm{A}}$ & $704 \pm 92^{\mathrm{A}}$ & $658 \pm 152^{\mathrm{A}}$ & $573 \pm 107^{\mathrm{A}}$ \\
\hline \multirow[t]{4}{*}{$\mathrm{K}$ concentration $\left(\mu \mathrm{mol} \mathrm{g}{ }^{-1} \mathrm{dw}\right)$} & Control & $317 \pm 12^{\mathrm{A}}$ & $145 \pm 13^{\mathrm{AB}}$ & $155 \pm 21^{\mathrm{AB}}$ & $181 \pm 23^{\mathrm{AB}}$ & $161 \pm 29^{\mathrm{AB}}$ & $192 \pm 19^{\mathrm{A}}$ \\
\hline & $\mathrm{AgNO}_{3}$ & $302 \pm 31^{\mathrm{A}}$ & $128 \pm 11^{\mathrm{A}}$ & $129 \pm 18^{\mathrm{A}}$ & $88 \pm 15^{\mathrm{A}}$ & $1789 \pm 25^{\mathrm{AB}}$ & $138 \pm 17^{\mathrm{A}}$ \\
\hline & Ag NPs & $370 \pm 27^{\mathrm{A}}$ & $186 \pm 16^{\mathrm{B}}$ & $292 \pm 54^{\mathrm{B}}$ & $258 \pm 48^{\mathrm{B}}$ & $265 \pm 28^{\mathrm{A}}$ & $220 \pm 32^{\mathrm{A}}$ \\
\hline & $\mathrm{Ag}_{2} \mathrm{~S}$ NPs & $364 \pm 42^{\mathrm{A}}$ & $121 \pm 12^{\mathrm{A}}$ & $180 \pm 34^{\mathrm{AB}}$ & $188 \pm 21^{\mathrm{AB}}$ & $118 \pm 30^{\mathrm{B}}$ & $168 \pm 18^{\mathrm{A}}$ \\
\hline
\end{tabular}

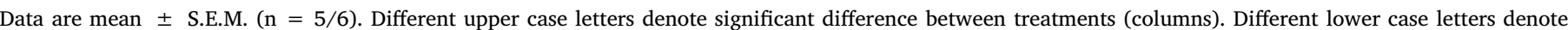

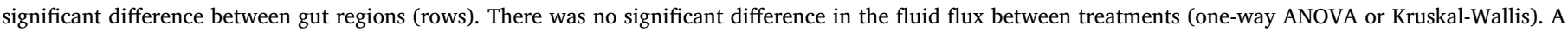

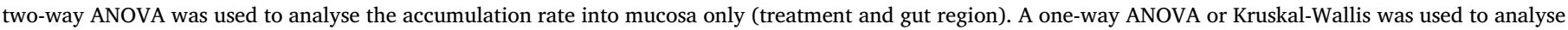

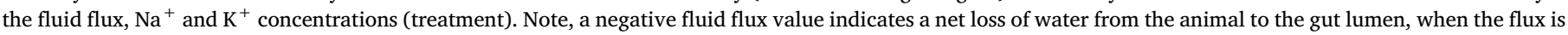
zero the water is in net balance.

$290 \mu \mathrm{mol} \mathrm{g}{ }^{-1} \mathrm{dw}$, twice that of the $\mathrm{AgNO}_{3}$ treatment which had $130 \mu \mathrm{mol} \mathrm{g}^{-1} \mathrm{dw}$ of $\mathrm{K}^{+}(P=0.021)$. Despite some variability in the $\mathrm{K}^{+}$ concentrations, none of the Ag treatments were significantly elevated compared to the controls.

\section{Discussion}

This study is the first to demonstrate the utility of the rodent gut sac technique for the bioaccumulation potential of different forms of silver, including ENMs. The highest accumulation of Ag from exposure to $\mathrm{AgNO}_{3}, \mathrm{Ag} \mathrm{NPs}$ or $\mathrm{Ag}_{2} \mathrm{~S}$ NPs were in the duodenum, jejunum and ileum. Specifically, the $\mathrm{AgNO}_{3}$ and $\mathrm{Ag} \mathrm{NP}$ treatments showed evidence of transepithelial accumulation of total $\mathrm{Ag}$ into the serosal compartment for the duodenum. Regardless of the material added, the biologically incorporated Ag (i.e., that in the mucosa, muscularis and serosal saline together) was $22 \%$ or much less of the dose administered into the gut lumen. Of this, only $14 \%$ or less was bioavailable to the serosal compartment, except in the $\mathrm{Ag}_{2} \mathrm{~S} \mathrm{NP}$ treatment where the serosal compartment did not show any detectable Ag, suggesting this treatment had a lower bioavailability compared to the pristine $\mathrm{Ag} \mathrm{NPs}_{\text {or }} \mathrm{AgNO}_{3}$.

\subsection{Bioavailability of the metal salt and nanomaterials in the gut}

The initial step in dissolved metal or ENM uptake is to make the test substance in the gut lumen bioaccessible to the unstirred layer of mucus on the surface of the gut. For dissolved metals, this depends heavily on their chemical speciation (e.g., Pb, Oomen et al., 2003). The chemical speciation of $\mathrm{AgNO}_{3}$ in the gut saline was calculated using Visual MINTEQ and showed only a tiny fraction of $\mathrm{Ag}^{+}$; with most of the total $\mathrm{Ag}$ present as less soluble chloride complexes, as expected for a saline which contains some $120 \mathrm{mmol}$ of chloride (Clark et al., 2019b). The $\mathrm{AgCl}$ complex is sparingly soluble and will precipitate onto the surface of the tissue (Clark et al., 2019b) and can therefore be washed off (Table 1). Consequently, the bioavailable fraction to the mucosa was $6 \%$ or less of the dose (Table 3 ). There appears to be no gut sac studies of $\mathrm{AgNO}_{3}$ in rodents, but these findings are similar to those for gut sacs of rainbow trout where $9 \%$ or less of the dose was in the mucosa (Clark et al., 2019b).

With regards to $\mathrm{Ag}$ NPs and $\mathrm{Ag}_{2} \mathrm{~S}$ NPs, the same approach to saline preparation was used here as in Clark et al. (2019b), which produced reasonable dispersions despite the high ionic concentration of the gut saline (Fig. 1). Dissolution of Ag from Ag NPs in the gut saline was tiny, and absent for the $\mathrm{Ag}_{2} \mathrm{~S}$ materials [see Clark et al. (2019b)]. It is therefore likely that the gut mucosa was initially exposed to dispersions of particles that settled onto the gut mucus and/or surface of the gut epithelium. Any surface bound total $\mathrm{Ag}$ from these exposures was readily washed off from the mucosa as evidenced from the higher concentrations of Ag in the luminal and EDTA washes (Table 1). This left only $5 \%$ or less of the dose bound on/in the mucosa. Thus, as observed in trout (Clark et al., 2019b), the nanomaterials are labile and most of the dose can be washed from the surface of the gut tissues. Similarly for Ag NPs in Caco-2 cells, some $1-6 \%$ of the dose is associated with the cells, depending on the size of the nanomaterial (van der Zande et al., 2016).

\subsection{Total silver accumulation in the gut tissue}

While gut sacs have some limitations for quantifying the uptake of chemicals (Foulkes, 1996), they retain most of the intrinsic physiological properties of the gut barrier, such as the transepithelial potential and solute permeability (Foulkes and Bergman, 1993; Handy et al., 2000). The gut sacs here were viable as shown by normal electrolyte concentrations and water fluxes (Table 4); with the latter comparable to previous water flux movements of typically around $10-30 \mu \mathrm{L} \mathrm{g}^{-1} \mathrm{~h}^{-1}$ in gut sacs from the small intestine of rodents (Birge et al., 1972). The water flux in gut sacs from the rat are also an order of magnitude lower than freshwater trout (Clark et al., 2019b); and in keeping with the requirement of terrestrial species to conserve water.

The intestinal ion transporters involved in the uptake of $\mathrm{Ag}^{+}$and any soluble anionic complexes of silver are uncertain, but $\mathrm{Ag}^{+}$shares some similarities with the $\mathrm{Cu}^{+}$ion that is transported across the intestine (Puchkova, 2019). The accumulation of the $\mathrm{Ag}$ from the $\mathrm{AgNO}_{3}$ treatment into the epithelial cells of the gut mucosa would involve facilitated diffusion through the apical membrane and down the electrochemical gradient, perhaps via the apical copper transporter one (Ctr1), or divalent metal transporter 1 (DMT1) that will carry a variety of metals (Gunshin et al., 1997). Tentatively, any intracellular $\mathrm{Ag}^{+}$ might be moved through the cell by $\mathrm{Cu}^{+}$chaperones, and then be exported by vesicular trafficking through the Golgi apparatus involving the Cu-ATPases (Puchkova, 2019). The copper transport system in the gut is also hijacked by other non-essential toxic metals such as $\mathrm{Hg}$ (Hoyle and Handy, 2005). Regardless of the mechanisms, the export of any dissolved $\mathrm{Ag}$ from inside the gut epithelial cells to the serosal compartment will be active and against the electrochemical gradient. 
Crucially, the Ag accumulation in the mucosa is not explained by solvent drag, as the metal flux is arguably smaller (i.e., different) and sometime in the opposite direction to that of the water (Table 4). This is consistent with previous measurements of the intrinsic permeability of the rat intestine (e.g., to ethanol) that only partly explain metal uptake (Foulkes and Bergman, 1993). The tissue accumulation rates into the mucosa of the gut for $\mathrm{Ag}$ from $\mathrm{AgNO}_{3}$ were $10-17 \mathrm{nmol} \mathrm{g}{ }^{-1} \mathrm{~h}^{-1}$ (Table 4), with the highest rate in the jejunum and ileum. These are slightly higher compared to that in the mid intestine of trout [ $\sim 9 \mathrm{nmol} \mathrm{g}{ }^{-1} \mathrm{~h}^{-1}$, Clark et al. (2019b)], as might be expected at the higher body temperature of mammals. However, the uptake rates for the metal salt (Table 4) are consistent with other reports in rodents for metals. For example, $\mathrm{Cu}$ in the in situ perfused rat intestine, about $22 \mathrm{nmol} \mathrm{g}{ }^{-1} \mathrm{~h}^{-1}$ (Wapnir, 1991). They are also broadly in the same magnitude as the uptake rates for $\mathrm{Ca}$ and $\mathrm{Mg}$ into the duodenal mucosa of $\sim 5$ and $2 \mathrm{nmol} \mathrm{cm}{ }^{2} \mathrm{~g}^{-1}$ (O'Donnell and Smith, 1973).

Nanomaterials are far too large to be taken up on solute transports (Handy et al., 2008) including the ion transporters involved in dissolved $\mathrm{Ag}$ uptake (ionic radius of $\mathrm{Ag}^{+}, \sim 115 \mathrm{pm}$ ). Nonetheless, for the nanomaterials, the pattern of accumulation of total $\mathrm{Ag}$ (form unknown in the tissue) from the $\mathrm{Ag} \mathrm{NP}$ exposure was broadly the same as $\mathrm{AgNO}_{3}$, except that the muscularis accumulated less $\mathrm{Ag}$, and the serosal concentration was mostly at or below the detection limit (Table 2). This implies some Ag was taken up into the gut epithelium, but not much was exported to the serosal side during the $4 \mathrm{~h}$ incubation. This is in keeping with oral gavage studies in vivo that show Ag NP exposures result in less Ag accumulation in the gut wall compared to the metal salt controls (van der Zande et al., 2012). Notably for the Ag NP exposures here, only the duodenum showed some net transepithelial uptake of total Ag to the serosal compartment (Table 2). Some total Ag uptake into the blood, and subsequently to the internal organs, from $\mathrm{Ag} \mathrm{NP}$ exposures has also been demonstrated in oral gavage studies with rodents (Loeschner et al., 2011; van der Zande et al., 2012). Furthermore, Loeschner et al. (2011), reported silver containing particles below the epithelial cells in the lamina propria of the lacteal region of the intestinal villus of the ileum, as well as some silver staining in the submucosa. This implies uptake of intact Ag NPs in the rat gut (e.g., by endocytosis), but once translocated through the epithelial cells, the Agcontaining material was captured by macrophages in the lacteal (Loeschner et al., 2011). This is consistent with the notion of ENMs being incorporated into the lymphatics of the villus, not the underlying musculature itself. Clark et al. (2019c) also confirmed, using single particle inductively coupled plasma mass spectrometry (spICP-MS), the likely internalisation of intact Ag NPs into the livers of trout fed diets containing the same Ag NPs used here.

In contrast to the $\mathrm{Ag} \mathrm{NP}$ treatment, $\mathrm{Ag}$ from the $\mathrm{Ag}_{2} \mathrm{~S}$ NP treatment was less bioavailable in the duodenum, with no detectable $\mathrm{Ag}$ in the

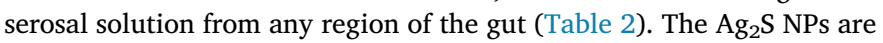
persistent, insoluble and show no silver dissolution (Clark et al., 2019b), and so must be presented to the gut in the particulate form. The anatomy of the gut barrier to ENMs is fundamentally similar in the ileum and duodenum [see our recent review of comparative gut anatomy with ENMs (van der Zande, 2020)] and the absorptive properties for substances are partly governed by the molecular characteristics and locations of the transport mechanisms in these regions of the gut. A role for the duodenum in the endocytosis of nanoparticles is likely, since it expresses the genes such as those for caveolin-1 known to be involved in endocytosis (Valasek et al., 2005), and also the genes involved in vesicular metal trafficking (Ravia et al., 2005). The duodenum has also shown greater uptake of simvastatin-loaded lipid NPs compared to the jejunum (Zhang et al., 2010). Additionally, gut sacs of the duodenum preferentially accumulate chitosan microparticles $(11.5 \mu \mathrm{m})$ compared to the jejunum and ileum (da Silva et al., 2009). The total $\mathrm{Ag}$ from $\mathrm{Ag}_{2} \mathrm{~S}$ does appear in the muscularis (Table 2), tentatively suggesting that some translocation of $\mathrm{Ag}_{2} \mathrm{~S}$ NPs through epithelial cells, but it does not appear in the serosal fluid. Clearly, Ag from
$\mathrm{Ag}_{2} \mathrm{~S}$ NPs is less bioavailable and processed in a different way to $\mathrm{Ag}$ from Ag NP exposures in the duodenum. Lower dietary bioavailability of the same $\mathrm{Ag}_{2} \mathrm{~S}$ NPs compared to Ag NPs used here has also been confirmed in vivo in trout (Clark et al., 2019a). The $\mathrm{Ag}_{2} \mathrm{~S}$ NPs had a slightly smaller primary diameter than the Ag NPs, so endocytosis of the former might result in slightly less total $\mathrm{Ag}$ in the tissue on a mass basis, or alternatively, smaller particles might be taken up at different rates to larger particles, both via distinct pathways. The mechanistic role of the intestine in differentiating forms of Ag-containing materials requires further investigation.

\subsection{Conclusions and regulatory perspectives}

In conclusion, the gut sac technique using rats can be employed to demonstrate the bioaccumulation potential of different $\mathrm{Ag}$ materials. The Ag bioavailability is only a modest fraction of the total dose, and based on the total $\mathrm{Ag}$ accumulation in the serosal saline of the duodenum, the gut sac method ranks the silver materials in the order: $\mathrm{AgNO}_{3}>\mathrm{Ag} \mathrm{NPs}>\mathrm{Ag}_{2} \mathrm{~S}$ NPs. This ranking suggesting that any existing oral bioaccumulation assessment for the dissolved metal would also be protective over the nano forms of silver. This is a similar ranking to previous gut sac studies in trout, where the materials were ranked in the order: $\mathrm{AgNO}_{3}>\mathrm{Ag} \mathrm{NPs}=\mathrm{Ag}_{2} \mathrm{~S}$ NPs. In the European Union, the 28-day oral toxicity tests [e.g., TG 407, OECD (2008)], or a similar protocol using rodents is a mandatory requirement for the registration of new substances and oral medicines where ingestion may be a concern. The EU directive 2010/63/EU on animal welfare also requires the minimal use of vertebrate animal testing. The TG 407 requires ten animals at each dose, at least three doses and a control; so not less than forty animals per test with potential for harm and distress over the twenty-eight days of the protocol. This compares to only five or six animals for the ex vivo gut sac method (i.e., reduction in animal use), and since the latter is on the gut removed after humane euthanasia, the distress to animals is also minimal. The gut sac method may enable a decision to waive TG 407 and similar in vivo tests entirely (i.e., replacement of animal use). We recommend that the rat gut sac method could be used to screen out ENMs that are not taken up by the gut, so that only materials 'of concern' go forward to in vivo animal testing in rodents. However, in the oral toxicity testing strategy for mammals, the replacement of the in vivo tests with in vitro alternative has not yet been realised. For ENMs, where materials might be made in a plethora of shapes and sizes of the same chemical substance, a tiered approach to oral toxicity testing is especially desirable; as we have suggested for environmental effects testing for the bioaccumulation potential of ENMs in fish (Handy et al., 2018). The gut sac method is also much closer to the in vivo condition than, for example, a gut cell line. However, both cell lines and gut sacs are closed systems and have some limitations for flux measurements. The metal accumulation in the gut sac is therefore intended as a predictive tool for the in vivo bioaccumulation hazard. It is also important to understand the mechanism of uptake across the gut epithelium, so that preventative measures can be put in place, such as safe-by-design manufacturing of ENMs, or remedies for acute oral poisoning. Here, the gut sac method may also find utility, such as using ion transport and/or endocytosis inhibitors to investigate the pathways involved.

\section{Credit author statement}

$\mathrm{RDH}$ was the lead investigator with responsibility for funding, resources, managing the work, checking the data collected and statistics, and editing of the drafts and final manuscript. NJC conducted the experiments with assistance from WW, analysed the data, drafted the initial manuscript and with input on all the revisions. 


\section{Declaration of competing interests}

The authors have no interests to declare.

\section{Acknowledgements}

This work was funded by the EU H2020 NanoFASE project, grant agreement No. 646002. The authors would like to thank Andrew Atfield for technician support, and Drs Andrew Fisher and Robert Clough for ICP-MS and ICP-OES support. We would also like to thank Charlotte Crowther for experimental support.

\section{References}

Birge, S.J., et al., 1972. Intestinal calcium transport - role of sodium. Science 176, $168-170$

Bobo, D., et al., 2016. Nanoparticle-based medicines: a review of FDA-approved materials and clinical trials to date. Pharmaceut. Res. 33, 2373-2387.

Bouwmeester, H., et al., 2014. State of the safety assessment and current use of nanomaterials in food and food production. Trends Food Sci. Technol. 40, 200-210.

Chaudhry, Q., et al., 2008. Applications and implications of nanotechnologies for the food sector. Food Addit. Contam. Part A-Chemistry Analysis Control Exposure \& Risk Assessment 25, 241-258.

Clark, N.J., et al., 2019a. Dietary exposure to silver nitrate compared to two forms of silver nanoparticles in rainbow trout: bioaccumulation potential with minimal physiological effects. Environmental Science-Nano. 6, 1393-1405.

Clark, N.J., et al., 2019b. An assessment of the dietary bioavailability of silver nanomaterials in rainbow trout using an ex vivo gut sac technique. Environmental ScienceNano. 6, 646-660.

Clark, N.J., et al., 2019c. Development of a suitable detection method for silver nanoparticles in fish tissue using single particle ICP-MS. Environmental Science-Nano. 6, 3388-3400.

da Silva, C.F., et al., 2009. The intestinal permeation of didanosine from granules containing microspheres using the everted gut sac model. J. Microencapsul. 26, 523-528.

Foulkes, E.C., 1996. Slices and sacs: limitations on metabolic and functional studies in kidney cortex and intestine. Proc. Soc. Exp. Biol. Med. 211, 155-162.

Foulkes, E.C., Bergman, D., 1993. Inorganic mercury absorption in mature and immature rat jejunum - transcellular and intercellular pathways in vivo and in everted sacs. Toxicol. Appl. Pharmacol. 120, 89-95.

Gitrowski, C., et al., 2014. Uptake of different crystal structures of $\mathrm{TiO}_{2}$ nanoparticles by Caco-2 intestinal cells. Toxicol. Lett. 226, 264-276.

Gunshin, H., et al., 1997. Cloning and characterization of a mammalian proton-coupled metal-ion transporter. Nature 388, 482-488.

Handy, R.D., et al., 2018. Proposal for a tiered dietary bioaccumulation testing strategy for engineered nanomaterials using fish. Environmental Science-Nano. 5, 2030-2046.

Handy, R.D., et al., 2008. Manufactured nanoparticles: their uptake and effects on fish-a mechanistic analysis. Ecotoxicology 17, 396-409.

Handy, R.D., et al., 2000. Mechanisms of gastrointestinal copper absorption in the African walking catfish: copper dose-effects and a novel anion-dependent pathway in the intestine. J. Exp. Biol. 203, 2365-2377.

Hoadley, J.E., Johnson, D.R., 1987. Effects of calcium on cadmium uptake and binding in the rat intestine. Fund. Appl. Toxicol. 9, 1-9.

Hoyle, I., Handy, R.D., 2005. Dose-dependent inorganic mercury absorption by isolated perfused intestine of rainbow trout, Oncorhynchus mykiss, involves both amiloridesensitive and energy-dependent pathways. Aquat. Toxicol. 72, 147-159.

Katouzian, I., Jafari, S.M., 2016. Nano-encapsulation as a promising approach for targeted delivery and controlled release of vitamins. Trends Food Sci. Technol. 53, $34-48$.

Kreyling, W.G., et al., 2017. Quantitative biokinetics of titanium dioxide nanoparticles after intravenous injection in rats: Part 1. Nanotoxicology 11, 434-442.

Lead, J.R., et al., 2018. Nanomaterials in the environment: behavior, fate, bioavailability, and effects - an updated review. Environ. Toxicol. Chem. 37, 2029-2063.

Linder, M.C., 2002. Biochemistry and molecular biology of copper in mammals. In: Massaro, E.J. (Ed.), Handbook of Copper Pharmacology and Toxicology. Humana Press, Totowa, NJ, pp. 3-32.

Loeschner, K., et al., 2011. Distribution of silver in rats following 28 days of repeated oral exposure to silver nanoparticles or silver acetate. Part. Fibre Toxicol. 8, 18.

Martirosyan, A., Schneider, Y.J., 2014. Engineered nanomaterials in food: implications for food safety and consumer health. Int. J. Environ. Res. Publ. Health 11, 5720-5750.

Minghetti, M., Schirmer, K., 2016. Effect of media composition on bioavailability and toxicity of silver and silver nanoparticles in fish intestinal cells (RTgutGC). Nanotoxicology 10, 1526-1534.

O'Donnell, J.M., Smith, M.W., 1973. Uptake of calcium and magnesium by rat duodenal mucosa analysed by means of competing metals. J. Physiol. 229, 733-749.

OECD, 2008. Test No. 407: Repeated Dose 28-day Oral Toxicity Study in Rodents. Organisation for Economic Cooperation and Development, Paris.

Oomen, A.G., et al., 2003. In vitro intestinal lead uptake and transport in relation to speciation. Arch. Environ. Contam. Toxicol. 44, 116-124.

Peters, R.J.B., et al., 2014a. Development and validation of single particle ICP-MS for sizing and quantitative determination of nano-silver in chicken meat. Anal. Bioanal Chem. 406, 3875-3885.

Peters, R.J.B., et al., 2014b. Characterization of titanium dioxide nanoparticles in food products: analytical methods to define nanoparticles. J. Agric. Food Chem. 62, 6285-6293.

Powell, J.J., et al., 2010. Origin and fate of dietary nanoparticles and microparticles in the gastrointestinal tract. J. Autoimmun. 34, J226-J233.

Puchkova, L.V., et al., 2019. Silver ions as a tool for understanding different aspects of copper metabolism. Nutrients 11, 1364. https://doi.org/10.3390/nu11061364.

Ravia, J.J., et al., 2005. Menkes copper ATPase (Atp7a) is a novel metal-responsive gene in rat duodenum, and immunoreactive protein is present on brush-border and basolateral membrane domains. J. Biol. Chem. 280, 36221-36227.

Reed, R.B., et al., 2014. Characterization of nanomaterials in metal colloid-containing dietary supplement drinks and assessment of their potential interactions after ingestions. ACS Sustain. Chem. Eng. 2, 1616-1624.

Tiede, K., et al., 2008. Detection and characterization of engineered nanoparticles in food and the environment. Food Addit. Contam. A. 25, 795-821.

Valasek, M.A., et al., 2005. Caveolin-1 is not required for murine intestinal cholestero transport. J. Biol. Chem. 280, 28103-28109.

van der Zande, M., et al., 2016. Different responses of Caco-2 and MCF-7 cells to silver nanoparticles are based on highly similar mechanisms of action. Nanotoxicology 10, 1431-1441.

van der Zande, M., et al., 2012. Distribution, elimination, and toxicity of silver nanoparticles and silver ions in rats after 28-day oral exposure. ACS Nano 6, 7427-7442.

van der Zande, M., et al., 2020. The gut barrier and the fate of engineered nanomaterials: a view from comparative physiology. Environ. Sci. J. Integr. Environ. Res.: Nano. https://doi.org/10.1039/D0EN00174K.

Wapnir, R.A., 1991. Copper-sodium linkage during intestinal-absorption - inhibition by amiloride. PSEBM (Proc. Soc. Exp. Biol. Med.) 196, 410-414.

Wapnir, R.A., Stiel, L., 1987. Intestinal-absorption of copper - effect of sodium. Proc. Soc. Exp. Biol. Med. 185, 277-282.

Weir, A., et al., 2012. Titanium dioxide nanoparticles in food and personal care products. Environ. Sci. Technol. 46, 2242-2250.

Wien, E.M., Van Campen, D.R., 1991. Ferric iron absorption in rats: relationship to iron status, endogenous sulfhydryl and other redox components in the intestinal lumen. J. Nutr. 121, 825-831.

Wilson, T.H., Wiseman, G., 1954. The use of sacs of everted small intestine for the study of the transference of substances from the mucosal to the serosal surface. J. Physiol 123, 116-125.

Zhang, Z.W., et al., 2010. The characteristics and mechanism of simvastatin loaded lipid nanoparticles to increase oral bioavailability in rats. Int. J. Pharm. 394, 147-153. 